\title{
A STUDY ON PREFERENCE OF SANSKRIT AS A SUBJECT OF LITERATURE
}

\section{DR. PURABI BAISHYA}

Assistant Professor, Department of Education, Gauhati University, Guwahati, Assam (India)

\begin{abstract}
The indigenous language of Sanskrit is perhaps the oldest language to be recorded. Since its inception, it has been the most important medium of bringing about a continuity to the Indian civilization. Sanskrit was spoken and used all over India and had gained its popularity in the West as well. It is even listed between the languages of the Eighth Schedule of the Indian Constitution. From the times of Gurukula system of Education till the present times, Sanskrit disseminates the cultural heritage of our country and plays the vital role in spiritual development of the students. But of late it has been noticed that growth of science and technology and growing preference of the students in studying technical subjects have let a setback to the learning of Sanskrit language. This is a matter of concern for one and all. Thus, an attempt has been made in the present study to understand the genesis of Sanskrit and its gradual decline to becoming a dead subject. For the aim of the research, a case study has been conducted in Pandu College of Guwahati. By interviewing the teachers and students, the objective of this study is to know the underlying causes behind the decline in preference and interest among students to study Sanskrit. In the light of the findings, suggestions will be given to improve the status of Sanskrit as a subject of study in higher education.

KEYWORDS: Indigenous, Sanskrit, Case Study
\end{abstract}

Received: Sep 02, 2020; Accepted: Sep 22, 2020; Published: Nov 12, 2020; Paper Id.: IJESRAUG202017

\section{INTRODUCTION}

The indigenous language of Sanskrit is perhaps the oldest language of Ancient India, with a documented oral and later written history of over 3000 years. It was the main liturgical language of Hinduism; the predominant language of majority works of Hindu philosophy and few of the main texts of Buddhism and Jainism. The Rig Veda happens to be the earliest surviving text of Sanskrit. Sanskrit, in its several alternatives and dialects has been the lingua franca of Ancient as well as Medieval India. Sanskrit even moved to Southeast Asia, parts of East Asia and Central Asia, emerging as a language of high culture and of local ruling elites in these areas. The body of Sanskrit literature encompasses a rich tradition of philosophical and religious texts, and also poetry, music, drama, scientific, technical as well as other texts. Sanskrit was one of the 22 languages written down in the Eighth Schedule of the Constitution of India. It carries on to be broadly employed as a ceremonial as well as ritual language in Hinduism also few Buddhist practices like hymns and chants.

Sanskrit has been a spoken language in the educated as well as the elite classes, and it has been also a language which should be perceived in an extensive circle of society. The broadly famous folk epics as well as stories like the Ramayana, the Mahabharata, the Bhagavata Purana, the Panchatantra and several other texts were all in the Sanskrit language. The Classical Sanskrit along its precise grammar has been hence the language of the Indian scholars as well as the educated classes. 
In accordance to the Dalai Lama, the Sanskrit language was a parent language which was in the foundation of several recent languages of India as well as the one that encouraged Indian concept to other remote nations. The Sanskrit language made a pan-Indic availability to data along with understanding in the ancient as well as medieval period. It made a cultural bond across the subcontinent. It associated scholars from distant parts of the Indian subcontinent like Tamil Nadu and Kashmir, states Deshpande, and those from distinct areas of researches, although there were variations in its pronunciation provided the first language of the corresponding speakers.

\section{NEED AND SIGNIFICANCE OF THE STUDY}

Sanskrit was vastly affected major recent languages of the Indian subcontinent, specifically the languages of the northern, western, central as well as eastern Indian subcontinent. In fact, the rich tradition of India is mostly rooted in Sanskrit. The knowledge of Sanskrit language and sutras was considered as a means of true scholarship. However, Sanskrit reduced beginning about also succeeding the 13th-century, coinciding with the origin of Islamic conquer of the Indian subcontinent with the decline of Kashmir about the 13th-century, a premier centre of Sanskrit literary creativity, Sanskrit literature there vanished, may be in the "fires that periodically engulfed the capital of Kashmir" or the "Mongol invasion of 1320" specifies Sheldon Pollock. Hindu rulers like Shivaji of the Maratha Empire, changed the procedure, through re-adopting Sanskrit and re-asserting their socio-linguistic recognition. When the British initiated English to India in the 19th century, understanding of Sanskrit as well as ancient literature extended to prosper as the learning of Sanskrit altered from a more conventional way into a form of systematically as well as relative scholarship reflecting that of Europe. But the glory that began with the gurukula system of education gradually declined in the later periods. In the modern age of Science and Technology, Sanskrit education in India passes through a crisis. The attitude of modern educationists who mark Sanskrit as a dead language and its inability to reconcile traditional and modern knowledge and methods have led to the rejection of the language at present. The Central Board of Secondary Education of India (CBSE), and various other state education boards, had created Sanskrit a substitute to the state's own formal language as a second or third language option in the schools it administers. That was correct of majority schools associated with the Indian Certificate of Secondary Education (ICSE) board, particularly in states where the official language was Hindi. Many colleges as well as universities in India were allotted departments for Sanskrit learning. Of all the disciplines widely offered at the undergraduate level, Sanskrit has the lowest cut-offs in the recent years. This is indicative of the low level of interest in the subject. For many admission-seekers, it is the ultimate back-up plan. So, despite efforts by the ruling Bharatiya Janata Party to push the study of Sanskrit in schools and the Rashtriya Swayamsevak Sangh's insistence that a "treasure house of knowledge is hidden in Sanskrit", a large section of students signing up for it in college every year wish they could have picked any other subject. Thus the preference of studying Sanskrit is gradually decreasing. Hence it was felt necessary to understand the genesis of Sanskrit and its gradual decline to becoming a dead subject.

\section{STATEMENT OF THE PROBLEM}

Based on the need and significance of the indigenous language in modern day context, the present study is titled as,

\footnotetext{
“A STUDY ON PREFERENCE OF SANSKRIT AS A SUBJECT OF LITERATURE"
}

\section{OBJECTIVES OF THE STUDY}


- To discover the causes of decrease in preference of Sanskrit as a subject of study in the area of study.

- To suggest measures to develop interest towards the study of Sanskrit as an honours subject.

\section{AREA OF STUDY}

The present study is conducted in Pandu College, Guwahati, Assam (India). Pandu College was established on $5^{\text {th }}$ September 1962. This college was associated with the Gauhati University. The college provides various courses in arts, commerce and science streams.

\section{DELIMITATION OF THE STUDY}

This current research has been determined to Pandu College, situated in Guwahati city of Assam, India.

\section{OPERATIONAL DEFINITION OF THE TERMS}

- Indigenous: The word indigenous depicts innate, natural and inherent characteristics originating in a particular region or country.

- Sanskrit: The Sanskrit verbal adjective sámskrta- was a compound word comprising of sams (together, good, well, perfected) and krta- (made, formed, work). It indicates a work which was "well prepared, pure and perfect, polished, sacred".

- Case Study: In the social sciences as well as life sciences, a case study was a study technique including an upclose, in-depth, and detailed study of a topic of research (the case), and its associated contextual states.

\section{METHOD USED}

The investigators used Case study method to understand the genesis of the present problem of study. It involves in- depth study and a detailed description of a single individual or institution or a small group.

\section{TOOLS USED FOR DATA COLLECTION}

To collect the necessary information, self- constructed interview schedules were constructed. They were administered to the teachers of the Sanskrit Department in a face- to- face interview.

\section{FINDINGS BASED ON THE CASE STUDY}

In accordance to the case study carried out, it was found that Pandu College introduced Sanskrit as a subject of Study in 1985 in both Under- Graduate Pass Course and Higher Secondary Course. Due to the increasing demands of the subject, in the later years, the college introduced major in Sanskrit in the year 2012. But of late, it has been noticed that there is a gradual decrease in interest among the students to study Sanskrit. Although, there is a seat capacity of 30 students, the Department of Sanskrit has failed to fill up the vacancies and enrolment is between 5 or 6 students for the last 5 years. The pass percentage of students in the final year of Undergraduate course has been between $65-70 \%$, which is a matter of concern. It was also found out that none of the undergraduate pass course students offering Sanskrit appeared in the final examination of 2017-18. According to the teachers of the Department, the students believe that Sanskrit is an outdated subject and lack career options for which they prefer the study of other disciplines rather than Sanskrit. Moreover the competitive world of today demands English as the most preferred language and medium of communication. Speaking in 
Sanskrit is a difficult task for which students have gradually lost interest in the subject. Besides with little or no interest in the subject, the students face difficulty in understanding the verses of the language. The Sanskrit Department of Pandu College has recently initiated writing of two Sanskrit words daily with their meanings in English as well as in Assamese on a whiteboard hanged outside the department .Its main motto is to popularise Sanskrit amongst the students and teachers of the other department of the College. Though a step forward, but there is still a long way to go to develop the preference towards the subject.

\section{SUGGESTIONS}

The situation of declining preference towards study of Sanskrit is emergent and Sanskrit now urgently needs special protection. While the Western countries like USA and Germany are developing interest in the study of Sanskrit, its gradual decline in the Indian Subcontinent calls for attention to develop the subject before it is too late. A few suggestions are given below:

- Provision of quality reading material for Sanskrit syllabus, and enhancing value- oriented programmes.

- Introduction of Distance Education streams that facilitate non-mainstream people to learn Sanskrit.

- Monitoring the development of the students through obtaining opinion from them with regard to the curriculum teaching-learning-assessment.

- In order to create teaching an interesting as well as agreeable experience, carries seminars, guest lectures, along with group discussions, often.

- Use of Flash cards as well as charts were create the study of Sanskrit more graphic also to keep the topic in memory constructively also to create the teaching lively as well as interesting.

- Extra study material was should be provided to the students to encourage them to study Sanskrit simply. Advise the students to look in on Sanskrit websites along with obtain access to further details as well as spread higher attentiveness towards the topic.

- Conduct certificate courses and Sanskrit spoken classes regularly.

- Introduce remedial classes for the students who fall behind in obtaining hold on the topic.

- Encourage he students of Sanskrit to participate in the academic activities of the department like seminars, mock lectures, quiz, recitation, elocution as well as essay writing competition.

- Develop awareness among students about the link that exist between Sanskrit and science.

- Introduce courses of creative writing in Sanskrit and develop more career options in the subject.

- Teach Sanskrit through the means of Yoga and meditation.

- Subscribe to the Sanskrit Newspapers and Journals and encourage the students to read them regularly.

- The mass media must play an important role in creating interest towards the subject. In this regard, All India Radio Programmes on Sanskrit Grammar Rules and initiation of a Sanskrit channel by the Doordarshan may be helpful. 
- Government must take initiatives to develop the subject by creating more employment opportunities and awarding scholarships to the students of Sanskrit department.

- Organize Sanskrit Book Fairs every year.

\title{
CONCLUSIONS
}

In conclusion it may be said that Sanskrit is the most useful tool to understand various ancient sciences, literature, alchemy, allegorical plays, mathematics, medicine, yoga, etc. It is proclaimed that it is the sweetest of all languages and thus regarded as the language of God. It initiates the students to the vast epics, profound scripture, subtle philosophy, voluminous mythology, exquisite poetry as well as so on and so forth. Study of these works enable a better understanding of the tradition, and shows the path of insight shared across cultures. Sanskrit literature incorporates a complete map of the human makeup: spiritual, mental, emotional as well as physical. It provides an extensive perspective of human nature as well as its part in creation of mankind. It makes all Indians more aware of their history, culture and roots of values. This subject was thought to raise the people of India spiritually and culturally in the views of swami Vivekananda. Pt. Jawaharlal Nehru also greatly emphasised on the importance of Sanskrit. He remarked, "India built up a magnificent language Sanskrit and through this language and its art and architecture, it sent its vibrant message to far away countries. It produced the Upanishads, the Gita and the Buddha. Hardly any language in the world has probably played as vital a part in the history of a race as Sanskrit has. It was not only the vehicle of highest thought and some of the finest literature, but it became the uniting bond for India, even though there were political divisions. The Ramayana and the Mahabharata were woven into the texture of millions of lives in every generation for a thousand years. I have often wondered if our race forgot the Buddha, the Upanishads and the great epics, what then would it be like? "But lack of interest among the Indian students to study Sanskrit language has led a setback to the subject. The subject has lost its value in the modern world of science and technology. It also lags competition and career options, thus becoming the last option for the students. The various commissions and committees have also failed to increase its status in educational institutions. So before it is too late, educationists, government and mass media must join hands to develop consciousness among students to study Sanskrit.

\author{
"Sanskrit is one thread on which the pearls \\ of the necklace of Indian culture are strung; \\ break the thread and all the pearls \\ will be scattered, even lost forever."- Dr. Lokesh Chandra
}

\section{REFERENCES}

1. Best, J. W. (1983). Research in Education. New Delhi: Prentice Hall of India Private Limited.

2. Livingstone, J. (2013, September 16). The Guardian. Retrieved September 19, 2018, from why you should learn a dead language: https://www.theguardian.com

3. BONDU, CHANDRA SEKHARAM, and RAMAKRISHNA SR. "AN APPROACH FOR GRAPHEME TO PHONEME ALIGNMENT FOR SANSKRIT TTS." International Journal of Computer Networking, Wireless and Mobile Communications (IJCNWMC) 4.2, Apr 2014, 93-100 
4. Prabhu, J. (2014, December 11). Here's why Sanskrit is not a dead language and should be at the core of school curriculum. Retrieved September 11, 2018, from DNA: https://www.dnaindia.com

5. NADIMPALLI, SATISH KUMAR. "SANSKRIT: A VAARADHI TO ENGLISH VOCABULARY." International Journal of Linguistics and Literature (IJLL) 5.4, Jun - Jul 2016; 33-38Sanskrit-Wikipedia. (n.d.). Retrieved from https://e4n.wikipedia.org >wiki>Sanskrit

6. Chouhan, Kalam. "Education system in ancient India." International Journal of History and Research (IJHR) 6.2 (2016).

7. Why did Sanskrit die as a language of the masses? (2016). Retrieved September 12, 2018, from Quora: https://www.quora.com 